\title{
PEMBERDAYAAN MASYARAKAT DALAM PENCEGAHAN DEMAM TYPHOID DENGAN PEMANFAATAN ANTISEPTIK JUS DAUN SIRIH HIJAU SEBAGAI PENCUCI BUAH DAN SAYUR
}

\section{COMMUNITY EMPOWERMENT IN THE PREVENTION OF TYPHOID FEVER USE GREEN BETEL LEAVES JUICE ANTISEPTIC AS WASHING FRUITS AND VEGETABLES}

\author{
${ }^{1)}$ Yusianti Silviani, ${ }^{2}$ Hari Saktiningsih \\ ${ }^{1)}$ Program studi D3 Teknologi Laboratorium Medis \\ ${ }^{2)}$ Program studi D4 Teknologi Laboratorium Medis \\ Sekolah Tinggi Ilmu Kesehatan Nasional \\ Jalan Solo-Baki, Kwarasan, Grogol, Sukoharjo, Jawa Tengah \\ Email: yusianti.silviani@gmail.com
}

\begin{abstract}
ABSTRAK
Buah-buahan dan sayuran mentah memiliki potensi terkontaminasi Salmonella penyebab tipes. Tujuan pengabdian ini adalah memberikan pengetahuan dan memberdayakan masyarakat untuk membuat antiseptik daun sirih yang dapat digunakan untuk mencuci buah dan sayur guna menghambat pertumbuhan bakteri Salmonella sp sebagai penyebab tipes. Metode yang digunakan yaitu ceramah, demonstrasi, praktek pembuatan antiseptik daun sirih hijau, dan diskusi. Kegiatan penyuluhan kesehatan dilaksanakan pada tanggal 23-24 November 2019 dengan diikuti 72 Ibu-Ibu PKK di Desa Jetis Kecamatan Baki, Kabupaten Sukoharjo. Hasil yang didapatkan adalah peningkatan pengetahuan mengenai pencegahan demam typhoid sebanyak $24 \%$, dan respon terhadap pembuatan antiseptic jus daun sirih hijau sebanyak $97 \%$.
\end{abstract}

Kata kunci: Daun Sirih Hijau; Tipes; Salmonella; Antiseptic; Buah dan Sayur

\begin{abstract}
Fruits and vegetables have the potential to be contaminated with Salmonella that causes typhus. This activity aims to provide knowledge and enhance the comunity to make betel leaf antiseptics that can be used to wash fruits and vegetables to prevent the growth of Salmonella sp bacteria as a cause of typhus. The method used is counseling by presentation, demonstration, practice, and discussion. Seventy-two people participated in extension activities. Activities were held in Jetis Village, Baki, Sukoharjo from 23-24 November 2019. This activity's results were an increase in knowledge about the prevention of typhoid fever by $24 \%$, and the response to the manufacture of antiseptic green betel leaf juice was $97 \%$.
\end{abstract}

Keywords: Green Betel Leaf; Typhus; Salmonella; Antiseptic; Fruits and Vegetables 
Yusianti Silviani, Hari Saktiningsih

Pemberdayaan Masyarakat Dalam Pencegahan Demam Typhoid Dengan Pemanfaatan Antiseptik Jus Daun Sirih Hijau Sebagai Pencuci Buah Dan Sayur

\section{PENDAHULUAN}

Demam typhoid merupakan penyakit sistemik yang disebabkan oleh Salmonella sp. (Febriana, 2018). Demam tifoid merupakan penyakit menular yang menyebabkan 216.000-600.000 kematian. Di Indonesia angka kesakitan tifoid adalah 81,7 per 100.000 penduduk, dengan sebaran penderita terbanyak adalah kelompok usia 2-15 tahun. Rata-rata angka kesakitan 500/100.000 penduduk dan kematian sekitar 0,6-5\%. Angka ini terus meningkat dari tahun ke tahun (Purba, Wandra, Nugrahini, \& Nawawi, 2016). Kasus demam tifoid yang harus menjalani perawatan di rumah sakit sebesar 20-40\% (Kemenkes RI, 2013).

Salmonella sp merupakan bakteri gram negatif fakultatif, berbentuk batang dan mempunyai flagel peritrik, tidak memfermentasi laktosa atau sukrosa, tumbuh pada suasana anaerob pada suhu $15-41{ }^{\circ} \mathrm{C}$ dengan suhu pertumbuhan optimal $37^{\circ} \mathrm{C}$ (Jawetz, 2010).

Salmonella $s p$ memiliki tiga antigen yaitu antigen $\mathrm{O}, \mathrm{H}$, dan Vi. Salmonella typhi, Salmonella choleraesuis, serta mungkin Salmonella paratyphi $A$ dan Salmonella paratyphi $B$ infektif bagi manusia. Transmisi dari bakteri ini biasannya melalui fekal-oral. Salmonella $s p$ akan ditularkan kepada manusia biasanya ketika manusia mengkonsumsi makanan yang tercemar oleh bakteri tersebut. Selain dari makanan juga bisa melalui binatang pengerat atau binatang lain (Wain et al., 2005).

Penularan Salmonella typhi terjadi melalui 2 cara yaitu pasien dengan demam typhoid atau carrier dan melalui makanan atau minuman yang terkontaminasi (Mansjoer, 2011).

Buah-buahan dan sayuran mentah memiliki potensi terkontaminasi mikroba termasuk juga mikroba patogen pada manusia. Hal ini dapat terjadi karena perlakuan sayuran segar yang kurang baik saat di tingkat petani, kebiasaan makan, serta peningkatan perdagangan sayuran segar (Santiago, et al., 2009).

Bakteri Salmonella $s p$ dapat ditemukan pada beberapa sayuran dan buah-buahan. Patofisiologi terjadinya demam typhoid dimulai dari Salmonella typhi menginvasi masuk ke dalam saluran intestinal manusia kemudian berhenti di nodus limfe mesenterika. Di nodus limfe mesenterika bakteri melakukan pembelahan diri, mengeluarkan LPS yang merupakan endotoksin ke aliran darah. Endotoksin akan difagositosis oleh makrofag, hal ini membuat pelepasan sitotoksin meningkat seperti IL-1, IL-6, dan TNF $\alpha$ yang akan mempengaruhi set point pada hipotalamus yang akan menimbulkan demam (Cita, 2011).

Tercatat sebanyak 20\% kasus keracunan makanan yang disebabkan oleh Salmonella typhi diakibatkan dari konsumsi produk segar siap santap sebagai contoh sayur mentah (Rianti et al., 2018). Penanganan sayuran segar dengan pengolahan yang minimal atau bahkan tanpa pengolahan perlu mendapat perhatian yang lebih. Perlakuan paling minimal pada sayuran segar yang diketahui masyarakat awam adalah pencucian. Pencucian diduga dapat menghilangkan kotoran dan kontaminan lainnya serta menurunkan potensi bahaya mikroorganisme. Meskipun dalam jumlah kecil namun bakteri ini tersebut cukup menimbulkan gejala sakit (James, 2006).

Tanaman daun sirih (Piper bettle Linn) mempunyai senyawa anti bakteri yaitu kavikol yang memiliki anti bakteri lima kali lebih kuat dari fenol serta imunomodulator dan mengandung minyak atsiri sampai 4,2\% (Reveny, 2011). Selain fenol, daun sirih mengandung terpenoid yang juga dapat menghambat pertumbuhan bakteri yaitu dengan mengganggu proses terbentuknya membran atau dinding sel sehingga terbentuk tidak sempurna (Sujono et al., 2019). 
Yusianti Silviani, Hari Saktiningsih

Pemberdayaan Masyarakat Dalam Pencegahan Demam Typhoid Dengan Pemanfaatan Antiseptik Jus Daun Sirih Hijau Sebagai Pencuci Buah Dan Sayur

Berdasarkan penelitian yang dilakukan oleh Haryuni, dkk (2017) menunjukkan bahwa jus daun sirih hijau memberikan pengaruh yang sangat nyata $(\mathrm{P}<0,01)$ terhadap diameter zona hambat bakteri Salmonella typhi. Senada dengan hal tersebut (Lutviandhitarani, Harjanti, \& Wahyono, 2015) menyatakan fraksi daun sirih efektif menghambat pertumbuhan bakteri Salmonella typhi.

Survei yang telah dilakukan pada kasus demam typhoid di Kabupaten Sukoharjo pada Tahun 2018 sebanyak 183 kasus, sedangkan pada Tahun 2019 dari bulan Januari sampai Juni terdapat 237 kasus. Pada Tahun 2019 di kecamatan Baki terdapat 201 kasus. Berdasarkan data kasus tersebut terlihat bahwa kasus demam typhoid mengalami peningkatan dari tahun 2018-2019.

Salah satu usaha preventif yang dapat dilakukan adalah dengan mencuci buah dan sayur. Bahan kimia yang digunakan untuk mencuci buah dan sayur memiliki efek negatif apabila tertelan, sehingga diperlukan temuan bahan alam yang aman untuk dikonsumsi dan tidak meninggalkan residu.

Tujuan pengabdian ini adalah memberikan pengetahuan dan memberdayakan masyarakat untuk membuat antiseptik buah dan sayur sebagai pengganti sabun pencuci buah dan sayur.

\section{MASALAH DAN LUARAN KEGIATAN}

Masalah yang dihadapi adalah tingginya angka kejadian demam typhoid dan kurangnya pengetahuan mengenai pencegahan demam typhoid. Target dalam kegiatan ini adalah peningkatan pengetahuan masyarakat mengenai pencegahan demam typhoid dan penggunaan jus darun sirih hijau sebagai antiseptik buah dan sayur.

Luaran yang dihasilkan adalah pemanfaatan daun sirih hijau sebagai antiseptik buah dan sayur sehingga mencegah terjadinya demam typhoid yang diakibatkan oleh makanan.

\section{METODE}

Langkah-langkah pelaksanaan untuk mencapai keberhasilan program pengabdian ini dilakukan dengan cara:

1. Penyuluhan kepada Ibu-Ibu PKK mengenai gejala, diagnosis dan pemeriksaan demam typhoid, serta manfaat daun sirih hijau sebagai antiseptik buah dan sayur, yang dilanjutkan dengan sesi tanya jawab.

2. Demonstrasi pembuatan dan penggunaan antiseptik jus daun sirih hijau sebagai pencuci buah dan sayur.

3. Pelatihan pembuatan antiseptik jus daun sirih hijau.

Metode yang digunakan pada penyuluhan ini adalah ceramah, demonstrasi, diskusi interaktif yang membahas mengenai gejala, diagnosa, pemeriksaan laboratorium dan pencegahan demam typhoid melalui penggunaan antiseptik jus daun sirih hijau sebagai pencuci buah dan sayur. Penyuluhan ini diselenggarakan pada hari Sabtu-Minggu, 23-24 November 2019 di Desa Jetis, Kecamatan Baki, Kabupaten Sukoharjo. Sasaran program penyuluhan adalah IbuIbu PKK Desa Jetis, Kecamatan Baki, Kabupaten Sukoharjo dengan jumlah peserta sebanyak 75 orang.

Pengukuran pengetahuan dilakukan dengan membagikan soal pre test sebelum presentasi dan soal post test di akhir acara. Keaktifan peserta dilihat melalui observasi secara langsung jumlah peserta yang hadir dan jumlah pertanyaan yang muncul, serta respon terhadap pembuatan produk dilakukan melalui pembagian kuesioner 
Yusianti Silviani, Hari Saktiningsih

Pemberdayaan Masyarakat Dalam Pencegahan Demam Typhoid Dengan Pemanfaatan Antiseptik Jus Daun Sirih Hijau Sebagai Pencuci Buah Dan Sayur

\section{HASIL DAN PEMBAHASAN}

Pelaksanaan edukasi pada pengabdian terhadap Ibu-Ibu PKK di Desa Jetis, Baki, Sukoharjo dilakukan melalui 3 tahap yaitu: Tahap 1 adalah penjelasan mengenai gejala, diagnosis, dan pemeriksaan laboratorium untuk demam typhoid, serta waktu yang tepat melakukan pemeriksaan laboratorium guna mendeteksi adanya demam typhoid.

Tahap kedua adalah edukasi mengenai daun sirih hijau, manfaat, cara pembuatan antiseptik serta cara penggunaan antiseptik jus daun sirih hijau. Tahap ketiga adalah demonstrasi dan praktek pembuatan antiseptik jus daun sirih hijau serta cara penggunaannya dalam pencucian buah dan sayur.

Pengukuran keberhasilan dapat dilihat dari kehadiran peserta, peningkatan nilai, keaktifan peserta, dan respon terhadap kegiatan pengabdian. Pada kegiatan ini peserta yang hadir adalah sebanyak $96 \%$ atau 72 orang dari 75 undangan (Gambar 1). Ini menunjukkan antusias Ibu-Ibu PKK Desa Jetis, Baki, Sukoharjo dalam meningkatkan pengetahuan mengenai demam typhoid.

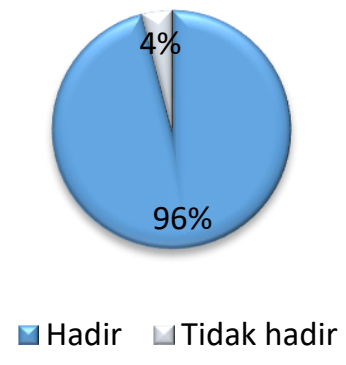

Gambar 1. Persentase kehadiran
Soal pre test dan post test disiapkan sebanyak 10 soal yang berisi mengenai gejala, diagnosis, pemeriksaan laboratorium demam typhoid, serta manfaat sirih hijau untuk antiseptik. Soal pre test diberikan sebelum kegiatan dimulai dan mendapatkan rata-rata nilai 71 , sedangkan soal post test yang dibagikan di akhir acara mendapatkan nilai rata-rata

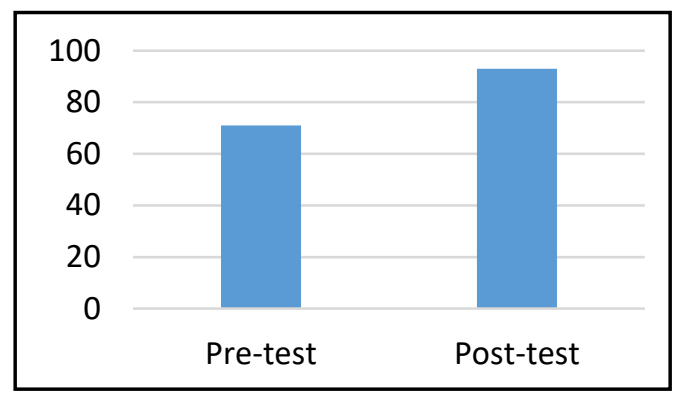

sebesar 93, dengan demikian terdapat peningkatan pengetahuan Ibu-Ibu PKK sebesar $24 \%$ seperti terlihat pada Gambar 2.

\section{Gambar 2. Diagram batang rata-rata nilai pre test dan post test}

Berdasarkan observasi langsung didapatkan 12 orang yang mengajuakan pertanyaan. Pertanyaan yang diajukan mengenai materi yang telah disajikan dan juga pengalaman dari Ibu-Ibu PKK mengenai demam typhoid yang pernah dialami.

Pembuatan produk antiseptik ini sangatlah mudah, murah, praktis dan dapat dibuat di rumah masing-masing. Selain itu, cara pembuatan antiseptik ini tidak memerlukan perlakuan khusus. Cara pembuatann antiseptik jus daun sirih adalah sebagai berikut: 1) Ditimbang sebanyak 1 gram (4-5 lembar) daun sirih hijau; 2) dilakukan pencucian daun sirih dengan air.3) ditiriskan; 4) ditambahkan 4 $\mathrm{ml}$ Aquadest; 5) dihaluskan dengan menggunakan blender; 6) dilakukan penyaringan pada campuran yang sudah halus; 7) Air Jus daun sirih ditampung dalam botol atau wadah yang sudah 
disterilkan dan siap digunakan (Haryuni $d k k, 2015$ )

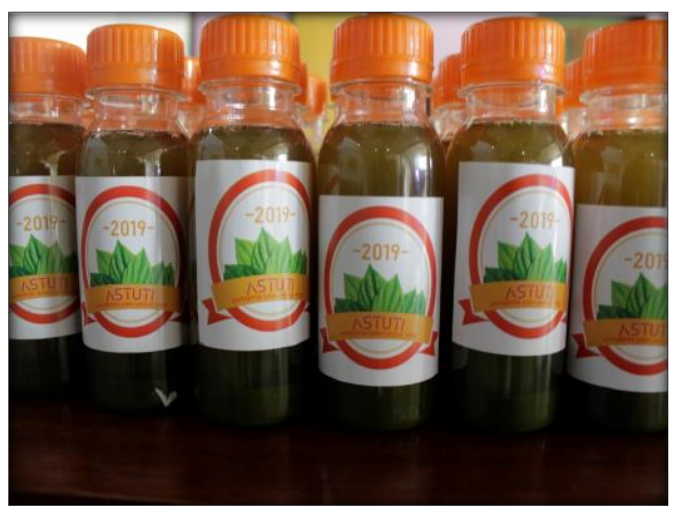

Gambar 3. Produk Antiseptik Jus Daun Sirih Hijau

Pada akhir kegiatan dilakuakn pengukuran respon peserta terhadap pembuatan antiseptik jus daun sirih hijau yang diukur melalui kuesioner. Hasil yang diperoleh adalah $97 \%$ peserta menyatakan kegiatan pengabdian ini bermanfaat dan akan mengaplikasikan ilmu yang didapat guna pencegahan demam typhoid.

Tanaman daun sirih (Piper bettle Linn) sudah terkenal manfaatnya sebagai antibakteri, salah satunya menghambat pertumbuhan bakteri Salmonella typhi. Hal tersebut sesuai dengan teori yang dikemukakan oleh (Reveny, 2011) dan diperkuat juga oleh penelitian (Haryuni et al., 2017) bahwa jus daun sirih memiliki daya hambat yang sangat nyata terhadap pertumbuhan bakteri Salmonella typhi. (Lutviandhitarani et al., 2015) mengatakan bahwa pada daun sirih hijau mengandung zat katekol, piragol, quinon, eugol, flavon, dan flavonoid termasuk dalam golongan fenol dan mempunyai kemampuan sebagai anti mikroba. Selain itu, daun sirih juga mengandung minyak atsiri sampai $4,2 \%$. Senyawa ini bersifat anti mikroba yang kuat karena dapat menghambat pertumbuhan beberapa jenis bakteri.

\section{SIMPULAN}

Kegiatan ini memberikan pengetahuan kepada Ibu-Ibu Desa Jetis, Baki, Sukoharjo mengenai manfaat daun sirih hijau sebagai antiseptik buah dan sayur dan ketrampilan dalam membuat antiseptik guna pencegahan demam typhoid. Tindak lanjut dari kegiatan ini adalah diharapkan masyarakat dapat menggunakan daun sirih untuk mencuci buah dan sayur.

\section{UCAPAN TERIMAKASIH}

Penulis mengucapkan terima kasih kepada Lempaga Penelitian dan Pengabdian STIKES Nasional atas bantuan dan dukungan pelaksanaan pengabdian masyarakat yang dialksanakan pada bulan November 2019. Ucapan terima kasih juga kepada para mahasiswa (Diva Novituria, Ratna Dianti Pramantari, Rosiana Kristianingrum, Shania Chandra Malinda, Bernadheta Noviana Subrata, Christina Herawati, Sita Fanny Himawan, Veronica Citra Ardiana) dari Program Studi D3 Teknologi Laboratorium Medis atas partisipasinya dalam kegiatan pengabdian ini

\section{DAFTAR PUSTAKA}

Cita, Y. P. (2011). Bakteri Salmonella typhi dan Demam Typhoid. Jurnal Kesehatan Masyarakat, 6(1), 43-46. https://doi.org/10.24893/jkma.v6i1.87

Haryuni, N., Widodo, E., \& Sudjarwo, E. (2017). Aktivitas Antibakteri Jus Daun Sirih (Piper betle Linn.) terhadap Bakteri Patogen dan Kualitas Telur Selama Penyimpanan. J. Ternak Tropika. 16(1), 48-5. https://doi.org/10.21776/ub.jtapro.201 5.016.01.8

Mansjoer, A. 2011 Kapita Selekta Kedokteran . Edisi 3. Jakarta : Medica Aesculpalus 
Yusianti Silviani, Hari Saktiningsih

Pemberdayaan Masyarakat Dalam Pencegahan Demam Typhoid Dengan Pemanfaatan Antiseptik Jus Daun Sirih Hijau Sebagai Pencuci Buah Dan Sayur

James, J. (2006). Overview of Microbial Hazard in Fresh Fruit and Vegetables Operations. Microbial Hazard Identification in Fresh Fruit an Vegetbles. Jhon Wiley \& Sons, Inc., Publication, New Jersey

Jawetz, Melnick, Adelberrgs. 2010. Medical Microbiology. Atlanta

Kemenkes RI. (2013). Sistematika Pedomam Pengedalian Penyakit Demam Tifoid. Bakti Husada, Jakarta

Lutviandhitarani, G., Harjanti, D. W., \& Wahyono, F. (2015). Green Antibiotic Daun Sirih (Piper betle 1.) Sebagai Pengganti Antibiotik Komersial untuk Penanganan Mastitis. Jurnal Agripet. 15(1), 2832. https://doi.org/10.17969/agripet.v15i1 .2296

Purba, I. E., Wandra, T., Nugrahini, N., Nawawi, S., \& Kandun, N. (2016). Program Pengendalian Demam Tifoid di Indonesia : tantangan dan peluang, Media Penelitian dan Pengembangan Kesehatan. 26(2), 99-108. http://dx.doi.org/10.22435/mpk.v26i2 $.5447 .99-108$

Reveny, J. (2011). Daya Antimikroba Ekstrak dan Fraksi Daun Sirih Merah ( Piper betle Linn .) Antimicrobial Activity of the Extract and Fraction of Red Betel Leaf ( Piper betle Linn .) Jurnal Ilmu Dasar Daya Antimikroba, 12 (1), 6-12.

Rianti, A., Buana, E.O.G.N., Kiyat, E.E., \& Harsojo, H. (2018). Eliminasi Bakteri Patogen pada Sayur dan Buah sebagai Bahan Baku Salad Siap Santap dengan Iradiasi Gamma. Jurnal Ilmiah Aplikasi Isotop dan Radiasi. 14(1), 59-65. http://dx.doi.org/10.17146/jair.2018.1 4.1.4246

Santiago, CQ., Rodas-Sua Rez, O.R., Zquez, C.R.V., Fernandez, F.J. 2009.
Prevalence of Salmonella in Vegetables From Mexico. Jurnal of Food Protection. 72(6), 1279-1282. https://doi.org/10.4315/0362-028x72.6.1279

Sujono, H., Rizal, S., \& Purbaya, S., \& Jasmansyah, J. (2019). Aktivitas Antibakteri Minyak atsiri Daun Sirih Hijau (Piper betle L) Terhadap Bakteri Streptococcus pyogenes dan Staphylococcus aureus. J. Kartika Kimia. 2(1), 30-36. https://doi.org/10.26874/jkk.v2i1.27

Wain, J., House, D., Zafar, A., Baker, S., Nair, S., Kidgell, C., ... Hasan, R. (2005). Vi antigen Expression in Salmonella enterica Serovar Typhi Clinical Isolates from Pakistan. Journal of Clinical Microbiology. 43 (3):1158-1163. https://jcm.asm.org/content/43/3/115 8 